\title{
Hypernatremia due to Urea-Induced Osmotic Diuresis: Physiology at the Bedside
}

\author{
Sonali Vadi, Kenneth Yim ${ }^{1}$ \\ Private Practitioner, Mumbai, Maharashtra, India, 'Director of Inpatient Hemodialysis-Davita Dialysis, University of Maryland Midtown Campus, Maryland, USA
}

\section{Abstract}

Hypernatremia secondary to urea-induced solute diuresis is due to the renal excretion of electrolyte-free water. This concept is explained here step-wise physiologically with the help of a clinical vignette.

Keywords: Electrolyte-free water clearance, hypernatremia, hypertonicity, osmotic diuresis, urea

\section{BACKGROUND}

Equation between solutes and water determines serum sodium levels. Increased urinary solute load in the form of urea nitrogen leads to urea-induced osmotic diuresis with increased free water loss and ensued hypernatremia.

\section{Clinical Vignette}

A 70-year-old woman was found unconscious at home. As per her family members, she complained of abdominal pain and diarrhea for 1 week's duration. Her baseline mental status was noted to be alert and oriented three days prior to presentation. Her medical history was significant for hypertension and osteoarthritis. There was no prior history of renal dysfunction. She has been a heavy alcohol drinker. Her medications included ibuprofen and cyclobenzaprine for osteoarthritis; lisinopril and felodipine for hypertension; aspirin and alprazolam. On examination, the patient was actively vomiting in the emergency department. Her vitals included temperature $97.3^{\circ} \mathrm{F}$, pulse 109 beats $/ \mathrm{min}$, blood pressure (BP) 113/79 $\mathrm{mmHg}$ in supine posture, and respirations 18 breaths/min. Physical examination revealed reduced skin turgor and dry mucous membranes, without any evidence of jugular venous distention. Her lung fields were clear to auscultation, with normal heart sounds. Her abdomen was soft and nontender and did not reveal any organomegaly. Neurologically, she was confused.

\begin{tabular}{|l|l|}
\hline \multicolumn{3}{c|}{ Access this article online } \\
\hline Quick Response Code: & Website: \\
& www.ijccm.org \\
\hline
\end{tabular}

Her initial laboratory data are presented in Table 1 and electrolyte trends during the hospital stay are summarized in Table 2.

\section{Acute issues at hand Diagnostic}

1. What is the cause of her renal dysfunction?

2. Why is she hypernatremic?

\section{Treatment}

1. Should she be urgently dialyzed?

2. How should her hypernatremia be managed?

\section{Discussion}

This complex pathological situation has been de-coded step-wise in a question format, with answers to each in two parts. The first part deliberates on physiology. The second one looks at the answer from a clinical perspective to help the reader manage with the same real-life situation.

\section{What is the cause of her renal dysfunction?}

Physiology

Factors affecting the glomerular hydrostatic pressure are arterial BP, afferent arteriolar resistance, and efferent arteriolar

\section{Address for correspondence: Dr. Sonali Vadi, Parel, Mumbai - 400 012, Maharashtra, India. E-mail: sonalivadi@hotmail.com}

This is an open access journal, and articles are distributed under the terms of the Creative Commons Attribution-NonCommercial-ShareAlike 4.0 License, which allows others to remix, tweak, and build upon the work non-commercially, as long as appropriate credit is given and the new creations are licensed under the identical terms.

For reprints contact: reprints@medknow.com

How to cite this article: Vadi S, Yim K. Hypernatremia due to urea-induced osmotic diuresis: Physiology at the bedside. Indian J Crit Care Med 2018;22:664-9. 
resistance. Renal autoregulation maintains blood flow and glomerular filtration rate (GFR) between mean arterial pressure (MAP) of 80 and $180 \mathrm{mmHg}$. This occurs at the level of afferent arterioles. Angiotensin II effects dilatation of the afferent arterioles with a simultaneous increase in the resistance of the efferent arterioles and a resultant increase in the glomerular hydrostatic pressure and GFR. Any reduction in the renal blood flow reduces glomerular hydrostatic pressure and GFR, the basis of prerenal azotemia, in turn stimulating the release of antidiuretic hormone (ADH). The result is an increase in the urine osmolality (Uosm). Ischemic acute tubular necrosis (ATN) can also occur in this state with additional hypotensive insult. ATN can be associated with an impaired response to ADH.

1. Fractional excretion of sodium $(\mathrm{FeNa})$ and Uosm in the setting of oliguria are useful tools in helping

\begin{tabular}{lc}
\hline \multicolumn{2}{l}{ Table 1: Laboratory data on presentation } \\
\hline Investigations & Patient values \\
\hline $\mathrm{Hb}(\mathrm{g} / \mathrm{dl}) / \mathrm{HCT}(\%)$ & $14.7 / 41.9$ \\
$\mathrm{WBC}($ cells per microliter) & 7900 \\
Platelet count (cells per microliter) & 308,000 \\
Sodium (mEq/L) & 148 \\
Potassium (mEq/L) & 5.5 \\
Chloride (mEq/L) & 99 \\
Bicarbonate (mEq/L) & 12 \\
Urea (mg/dl) & 297 \\
Creatinine (mg/dl) & $16.3 \mathrm{mg} / \mathrm{dl}$ \\
Glucose (mg/dl) & $195 \mathrm{mg} / \mathrm{dl}$ \\
Albumin (mg/dl) & $3.3 \mathrm{mg} / \mathrm{dl}$ \\
Lipase (U/L) & 1343 \\
Urine analysis & Albumin 25, occult blood 25, \\
& moderate amorphic sediment \\
Arterial blood gas & $7.31 / 25 / 112 / 12$ "R" air \\
CT scan brain (without contrast) & No acute intracranial \\
& pathology identified \\
\hline HB: Hemoglobin, HCT: Hematocrit, WBC: White blood cell
\end{tabular}

distinguish the cause of acute renal failure, hypovolemic vs. post-ischemic ATN. Reduced response to ADH in postischemic ATN is suggested by a low Uosm. ${ }^{[1]}$

\section{At the bedside}

The enormity of azotemia cannot be used to determine its origin - prerenal, renal, or postrenal.

The cause of her renal dysfunction is prerenal:

a. Autoregulation can be impaired in the elderly and in hypertensive patients. ABP of 113/79 mmHg with an MAP of $90.2 \mathrm{mmHg}$ may not have been sufficient to maintain adequate renal blood flow in this patient

b. Review of her meds suggests that she was on both ibuprofen and lisinopril. Ibuprofen can inhibit afferent arteriolar dilatation with a consequential reduction in renal blood flow and hence the GFR ${ }^{[2]}$

c. Lisinopril decreases resistance in efferent arterioles which can further reduce the GFR. ${ }^{[3]}$ The half-life of lisinopril increases because of reduced GFR. Moreover, volume depletion leads to increased concentration of medications in the lumen of renal tubules for a longer period with consequential prolonged duration of action

d. Further, She was hypovolemic secondary to gastrointestinal losses with an $\mathrm{FeNa}<! \%$ and Urine $\mathrm{Na}<$ $10 \%$

e. The high Uosm in this patient makes the diagnosis of ATN less likely.

\section{What led to her catabolic state? \\ Physiology}

During illness and starvation, muscle proteins break down to provide energy, generating urea nitrogen. Protein breakdown generates ammonium ions. Ammonium ions subsequently are converted to urea nitrogen and water in the liver urea cycle. Resultant urea nitrogen is excreted through the kidneys. The

\begin{tabular}{|c|c|c|c|c|c|c|c|c|c|c|c|c|}
\hline Date & BUN & $\begin{array}{c}\text { Serum } \\
\text { Creat }\end{array}$ & $\begin{array}{c}\text { Serum } \\
\mathrm{Na}^{+}\end{array}$ & $\mathbf{K}^{+}$ & Plasmaosmol & $\begin{array}{l}\text { Urine } \\
\text { osmol }\end{array}$ & $\begin{array}{l}\text { Urine } \\
\text { Creat }\end{array}$ & $\begin{array}{l}\text { Urine } \\
\mathrm{Na}^{+}\end{array}$ & $\begin{array}{c}\text { Urine } \\
\mathrm{K}^{+}\end{array}$ & $\begin{array}{c}\text { Urine } \\
\mathrm{Cl}^{-}\end{array}$ & $\begin{array}{l}\text { Urine } \\
\text { urea }\end{array}$ & $\begin{array}{l}\text { Urine } \\
\text { output }\end{array}$ \\
\hline August 7 & 13 & 0.8 & 143 & 3.6 & - & - & - & - & - & - & - & - \\
\hline March 31 & 297 & 16.3 & 148 & 5.5 & - & - & 546 & $<10$ & 51 & $<15$ & 531 & 2500 \\
\hline April 1 & 291 & 13.0 & 150 & 5.0 & 430 & - & - & - & - & - & - & - \\
\hline April 1 & 270 & 8.5 & 157 & 4.2 & - & - & - & - & - & - & - & 2700 \\
\hline April 2 & 214 & 4.5 & 159 & 4.9 & 407 & 440 & 56 & 51 & 6.7 & 46 & 835 & - \\
\hline April 2 & 199 & 4.1 & 160 & 4.0 & - & - & - & - & - & - & - & - \\
\hline April 2 & 174 & 3.0 & 159 & 3.8 & - & - & - & - & - & - & - & 3800 \\
\hline April 3 & 127 & 1.8 & 159 & 3.9 & 374 & - & - & 34 & - & 37 & 929 & - \\
\hline April 3 & 91 & 1.5 & 163 & 4.0 & - & - & - & - & - & - & - & 2300 \\
\hline April 4 & 72 & 1.4 & 159 & 3.9 & - & - & - & - & - & - & - & - \\
\hline April 4 & 51 & 1.2 & 149 & 3.5 & - & - & - & - & - & - & - & 1975 \\
\hline April 5 & 30 & 1.0 & 152 & 3.4 & - & - & - & - & - & - & - & - \\
\hline April 5 & 18 & 1.0 & 151 & 3.5 & - & - & - & - & - & - & - & 2990 \\
\hline
\end{tabular}

BUN: Blood urea nitrogen (mg/dl), Creat: Creatinine (mg/dl), $\mathrm{Na}^{+}$: Sodium (mmol/L), $\mathrm{K}^{+}$: Potassium (mmol/L), Plasma osmol: Plasma osmolality (mOsm/kg), Urine osmol: Urine osmolality ( $\left.\mathrm{mOsm} / \mathrm{kg} \mathrm{H}_{2} \mathrm{O}\right), \mathrm{Ur}$ creat: Urine creatinine $(\mathrm{mg} / \mathrm{dl}), \mathrm{Ur} \mathrm{Na}^{+}$: Urine sodium $(\mathrm{mmol} / \mathrm{L}), \mathrm{Ur} \mathrm{K}{ }^{+}$: Urine potassium $(\mathrm{mmol} / \mathrm{L})$, $\mathrm{Ur} \mathrm{Cl}^{-}$: Urine chloride (mmol/L), Ur urea: Urine urea (mg/dl), U/o: Urine output (ml/24 h) 
urea cycle accounts for $90 \%$ of nitrogen-containing compounds in the urine.

\section{At the bedside}

Stress of acute illness (diarrhea) increased her protein catabolism. Bacterial sepsis increases urinary nitrogen excretion. Combined with these, her renal dysfunction would have contributed to high plasma urea levels. Side effects of negative protein balance are not tolerated by those with already reduced lean body mass reserves. Endogenous protein wasting contributed to this patient's osmotic diuresis.

\section{What is the clinical significance of osmotic diuresis? Physiology}

Excessive glucose or urea nitrogen can lead to osmotic diuresis. Consequent polyuria reduces extracellular fluid (ECF) volume. Sodium lost in the urine is relatively less than the amount of water diuresis, leading to hypernatremia.

Calculating urinary osmoles and their nature helps in the diagnosis of solute diuresis. ${ }^{[4]}$

Formula a:

Calculated Uosm $=2 \times($ urine sodium $[\mathrm{mmol} / \mathrm{L}]+$ urine potassium $[\mathrm{mmol} / \mathrm{L})+\frac{(\text { urine urea nitrogen }[\mathrm{mg} / \mathrm{dl}])}{2.8}+$ $\frac{\text { (urine glucose }[\mathrm{mg} / \mathrm{dl}] \text { ) }}{18}$

Formula b: Daily excretion of urinary osmoles (calculated) $=$ calculated Uosm $\times 24$-h urine volume in liter

Formula c: Daily excretion of urinary osmoles (measured) $=$ measured Uosm $\times 24$-h urine volume in liter

Formula d: Unmeasured osmoles = measured osmoles - calculated osmoles $=$ Formula $\mathrm{c}-$ Formula $\mathrm{b}$

- Uosm >300 $\mathrm{mOsm} / \mathrm{L}$ and urine solute load $>1000 \mathrm{mOsml} /$ day $=$ osmotic diuresis.

\section{At the bedside}

High and rising trends of urine urea at $835 \mathrm{mg} / \mathrm{dl}$ (refer to laboratory value of April 2) and $929 \mathrm{mg} / \mathrm{dl}$ (refer to laboratory value of April 3) were associated with urea-induced osmotic diuresis. This signifies the necessity to investigate solute excretion in patients with polyuria and hypernatremia.

Calculation: Daily excretion of urinary osmoles (measured) $=440 \times 3.8=1672 \mathrm{mOsm} /$ day.

Excessive urea production following substantial amounts of protein administered in nutrition leads to osmotic diuresis. Ensuing loss of water and electrolytes in the urine leads to dehydration which can be followed by peripheral circulatory failure, a shock state. Volume loss in the form of free water excretion, reduced renal perfusion, and increased protein breakdown (as in the scenario discussed) leads to a rise in blood urea nitrogen (BUN).

\section{What is the cause of hypernatremia in this patient? Physiology \\ The mechanisms of hypernatremia include:}

a. Hypovolemic hypernatremia: Reduction in total body water $>>$ reduction of total body sodium (fluid loss)

b. Euvolemic hypernatremia: Reduction in total body water; total body sodium is normal (fluid loss)

c. Hypervolemic hypernatremia: Total body water is normal; total body sodium is increased (sodium gain).

\section{At the bedside}

Hypovolemia resulting from vomiting, diarrhea, and solute diuresis (hyperosmolar urine rich in urea but poor in sodium and potassium led to loss of free water) contributed to her hypernatremia. Furthermore, the patient's impaired thirst response in addition to her altered mental status further precluded her water ingestion.

\section{How can sodium trends (rise, followed by downward trend) be explained? \\ Physiology}

Water follows solute electrolytes (i.e., sodium). However, water excreted without solute electrolytes $=$ free water clearance (FWC).

FWC indicates how body handles the water load. ${ }^{[5]}$

- $\quad$ Positive FWC = Amount of water excreted in urine more than what is needed to make urine isosmotic to plasma $=$ kidneys are producing dilute urine through the excretion of solute-free water

- $\quad$ Negative FWC = Amount of water excreted in urine less than what is needed to make urine isosmotic to plasma $=$ kidneys are conserving water resulting in the production of concentrated urine $=$ free water reabsorption.

If answer is in negative, interpreting by the above formula would mean that the patient should not have developed hypernatremia. ${ }^{[6]}$

Electrolyte-FWC (EFWC) theory (i.e., urine electrolytes < plasma electrolytes) explains the occurrence of hypernatremia here. ${ }^{[7]} \mathrm{FWC}$ is the amount of water cleared from the plasma, resulting in urine or the excretion of water independent of solutes. Hypotonic urine increased water loss in urine, leading to an increase in plasma solutes.

$\mathrm{EFWC}=$ Urine volume $\times\left(1-\left[\frac{\text { urineNa }+ \text { urineK }}{\text { serumNa }+ \text { serumK }}\right]\right)$

Or

modified Kurtz equation $^{[5]}=$

Urine volume $\times\left(1-\left[1.03 \times \frac{\text { urineNa }+ \text { urineK }}{\text { serumNa }+28.3}\right]\right)$

At the bedside

Refer to the laboratory values of April 2 [Table 2]:

$\mathrm{FWC}=([51+6.7] /[159+4.9])=(57.7 / 163.9)=0.35$ 
This urine is low in sodium and potassium, the ions that primarily determine Posm (sum of urine cations $=57.7$ which is less than sum of plasma cations $=163.9$ ). Hence, the urine is hypotonic or dilute. Thirty-five percent of the urine is thus electrolyte containing, and $65 \%$ of the urine is electrolyte-free water. Thus, although her Uosm is high, her urine tonicity is low. Her urine is almost equivalent to electrolyte-free water. This loss of electrolyte-free water led to an increase in her plasma sodium levels.

Furthermore, with the patient's urine output of $158 \mathrm{ml} / \mathrm{h}$ ( $3800 \mathrm{ml} /$ day), she is losing $0.65 \times 158 \mathrm{ml} / \mathrm{h}=103 \mathrm{ml}$ of free water per hour in the urine. Hence, water replacement must be equal to $103 \mathrm{ml} / \mathrm{h}$ to replace her on-going water losses in the urine. Now, this patient was receiving $0.9 \mathrm{NS}$ at $250 \mathrm{ml} / \mathrm{h}$. There was on-going hypotonic fluid loss with no effective free water repletion. This was the primary reason that her serum sodium levels rose to $160 \mathrm{mEq} / \mathrm{L}$. Her fluids were later changed to $0.45 \mathrm{NS}$ at $180 \mathrm{ml} / \mathrm{h} .0 .45 \mathrm{NS}$ fluid is hypotonic in comparison to the hypertonic plasma, thus providing free water.

Thus, EFWC on April 2 was more than that on March 31 [Table 3], denoting worsening hypernatremia.

\section{What are the determinants of plasma osmolality and urine osmolality? \\ Physiology \\ Osmolality refers to the concentration of all the solutes $=\mathrm{a}$ measure of number of particles in a solution}

Tonicity refers to the concentration of effective osmoles $=$ sum of concentration of solutes that can exert an osmotic force across a membrane. Its value is less than osmolality.

\section{Plasma osmolality (275-295 m0sml/l)}

Osmolality depends upon the total number of active ions or molecules in the fluid (plasma or urine). Tonicity is determined by osmoles that influence movement of water across the cell membranes, i.e., sodium and potassium. Hypernatremia is associated with to hypertonicity. Urea is of a smaller molecular weight and readily crosses the cell membranes. ECF (urea) = intercellular fluid (ICF [urea]). Thus, as it does not affect the plasma tonicity, urea is not an effective osmole. ${ }^{[8]}$

\section{Urine osmolality}

Uosm reflects the ability of the kidneys to concentrate the urine. Solutes in the urine that determine its osmolality include electrolytes, creatinine, urea, and uric acid. Urea readily crosses the cell membranes and hence does not lead to the development of an osmotic gradient, an "ineffective osmole." However, when the urinary excretion rate of urea is high, all of it may not be renally reabsorbed. In such instances, urea

\begin{tabular}{|c|c|c|}
\hline Dates & $31^{\text {st }}$ March & $2^{\text {nd }}$ April \\
\hline EFWC $=$ Urine volume $\times\left(1-\left[\frac{\text { urineNa }+ \text { urineK }}{\text { serumNa }+ \text { serumK }}\right]\right)$ & 1.52 & 2.47 \\
\hline
\end{tabular}

acts as an "effective" osmole in the inner medullary collecting duct (MCD) and leads to excretion of water. ${ }^{[8]}$

Urea is an "ineffective" urine osmole when there is a high rate of electrolyte excretion and is an "effective" osmole when there is a low rate of excretion of electrolytes. ${ }^{[9]}$ Uosm is low to normal following renal loss of water (e.g., diabetes insipidus, partial defect in ADH release or response). Uosm is high following extrarenal loss of water (e.g., loss through skin, gastrointestinal [GI], lungs; high sodium intake).

\section{At the bedside}

1. Urinary loss of urea $(835 \mathrm{mg} / \mathrm{dl})$ in this patient increased the Uosm $\left(440 \mathrm{mOsm} / \mathrm{kg} \mathrm{H}_{2} \mathrm{O}\right)$. As urea does not carry any charge, sodium is not simultaneously excreted with it. This increased her Posm. ${ }^{[10,11]}$ Excretion of urine in which the sum of the cations $(\mathrm{Na}+\mathrm{K})$ is less than that of the sum of plasma cations $(\mathrm{Na}+\mathrm{K})$ implies that the urine is hypotonic relative to the serum and that electrolyte-free water is being lost. Thus, a better way to evaluate water excretion is by calculating EFWC.

\section{What is the clinical significance of hypertonicity? Physiology}

Hypertonicity leads to fluid shift intracellular to the extracellular space, leading to the shrinkage of cells. Rapidity of its development influences the severity of clinical manifestations.

\section{At the bedside}

Extremes of age are more susceptible to its effects such as nausea, vomiting, thirst, lethargy, irritability, seizures, or coma.

\section{What is the reason for polyuria in this patient? Physiology \\ Osmotic regulation}

Stimulus for ADH secretion is a rise in Posm. ADH is very sensitive to the changes in Posm. Even a $1 \%$ change in plasma osmolality stimulates ADH release. Normally, the osmotic threshold for ADH secretion is a Posm range of 275-290 mOsm $/ \mathrm{kg} \mathrm{H}_{2} \mathrm{O}$. However, although urea increases the Posm, it is "ineffective" in stimulating $\mathrm{ADH} \cdot{ }^{\left[{ }^{[2]}\right.}$ In addition, the nephrogenic response to ADH following postischemic ATN may be impaired.

Urine volume $=$ clearance of water $($ water diuresis $)+$ clearance of osmoles (osmotic diuresis).

Urine flow rate $=$ Number of effective urine osmoles/ concentration of effective urine osmoles. ${ }^{[8]}$ Excretion of an osmotically active solute through the kidneys leads to excretion of water (i.e., solute or osmotic diuresis). Increased urine output with a spot Uosm of $>300 \mathrm{mOsm} / \mathrm{kg},{ }^{[8]}$ and a urine sodium of 50-80 mEq/L suggests osmotic diuresis. Total solute diuresis $=$ Uosm $\times$ daily urine volume. Solute-driven water diuresis is typically $600-900 \mathrm{mOsm} /$ day (normally contributed by sodium, potassium, ammonia, and urea). An increase in urinary excretion of solutes would then lead to total solute diuresis levels of $>1000 \mathrm{mOsm} /$ day. 


\section{At the bedside}

1. Table 4 shows the patient's calculated and measured serum osmolality on her initial 3 days of hospitalization. Her osmolar gap of $<10 \mathrm{mOsm} / \mathrm{L}$ suggests that urea, the "ineffective osmole," was a contributing factor to the high Posm

2. The urinary osmolality of this patient is $440 \mathrm{mOsmol} / \mathrm{kg}$ $\mathrm{H}_{2} \mathrm{O}$. Hence, diabetes insipidus is unlikely as the cause of polyuria in this patient

3. A Uosm $>300 \mathrm{mOsm} / \mathrm{kg}$ and urine osmole excretion rate of $>600-900 \mathrm{mOsml} / \mathrm{day}$ (urine osmole excretion rate in this patient $=$ Urine volume $/$ day $\times$ $\mathrm{Uosm}=3.8 \mathrm{~L} \times 440 \mathrm{mOsmol} / \mathrm{kg} \mathrm{H}_{2} \mathrm{O}=1672 \mathrm{mOsml} /$ day) support more of an osmotic diuresis

4. Her blood sugar levels of $195 \mathrm{mg} / \mathrm{dl}$ do not suggest urinary glucose losses as the main driving force for osmotic diuresis

5. The urine sodium of $51 \mathrm{mmol} / \mathrm{L}$ and potassium of $6.7 \mathrm{mmol} / \mathrm{L}$ coupled with a high Uosm of $440 \mathrm{mOsmol} / \mathrm{kg}$ $\mathrm{H}_{2} \mathrm{O}$ suggest the presence of a nonelectrolyte osmole in the urine to account for the excess water loss in the urine. The extremely high blood urea of $214 \mathrm{mg} / \mathrm{dl}$ most likely explains her urea-induced osmotic diuresis. With urea of $835 \mathrm{mg} / \mathrm{dl}$ and urine volume of $3.8 \mathrm{~L} /$ day, this patient excreted $3173 \mathrm{mg}$ of urea

6. This patient was living alone and had a history of poor oral intake, with excessive alcohol intake. Catabolism of her lean body mass in addition to her resolving acute renal failure was the source of her excessive urine urea nitrogen

7. Again, the total solute diuresis in this patient would be $1672 \mathrm{mOsm} /$ day, supporting osmotic diuresis

8. This urinary excretion of free water in the setting of serum hypertonicity also suggests an impaired ADH-renal response $^{[13]}$

9. Polyuria could also be attributed to aggressive fluid resuscitation following initial oliguria.

How should her renal failure be managed? Should she be dialyzed?

Physiology

Urea readily crosses cell membranes. Its concentration equilibrates between the ECF and ICF. Urea is an "ineffective osmole" as it does not affect the plasma tonicity. However,

\begin{tabular}{lccc}
\hline Table 4: Osmolar gap & & & \\
\hline Time & $\begin{array}{c}\text { 1 April } \\
\text { (4:50 AM) }\end{array}$ & $\begin{array}{c}\text { 2 April } \\
\text { (8 AM) }\end{array}$ & 3 April \\
& (6 AM) \\
\hline Measured osmolality & 430 & 407 & 374 \\
Sodium & 150 & 160 & 159 \\
Potassium & 5.0 & 4.0 & 3.9 \\
BUN & 291 & 199 & 127 \\
Glucose & 241 & 214 & 116 \\
Calculated osmolality & 427.3 & 405.6 & 377.6 \\
\hline
\end{tabular}

this requires several hours to reach equilibrium across the cell membranes. Thus, following acute dialysis, urea acts as an "effective osmole." Rapid removal of urea following hemodialysis reduces Posm. The resulting osmotic gradient causes a rapid shift of water into the cells with potential swelling of the brain. Brain edema with resulting neurological symptoms is clinically manifested in dialysis disequilibrium syndrome. ${ }^{[14]}$

\section{At the bedside}

With a $\mathrm{FeNa}<1 \%$ in the setting of initial oliguria and supportive clinical history, the cause of renal failure in this patient is most likely prerenal. Hence, intravenous (IV) hydration is the initial treatment of choice and not dialysis. This patient would also be at a higher risk for dialysis disequilibrium.

\section{How much is her water deficit? \\ Physiology}

Hypernatremia leads to free water deficit. Free water deficit $=$ Normal total body water - current total body water. If only the free water deficit is replaced without accounting for ongoing losses, hypernatremia will persist. Supplementing both the deficit and the active losses (free water deficit + EFWC) will help resolve hypernatremia.

\section{At the bedside}

On April 2, her hypernatremia associated free water deficit $=3.78 \mathrm{~L}$. Ongoing osmotic diuresis causes additional electrolyte free water to be lost in urine $=\mathrm{EFWC}=2.16 \mathrm{~L}$. Therefore, the patient's total free water deficit by the end of the day will is estimated to be $5.94 \mathrm{~L}$.

\section{How will you prescribe the intravenous fluid orders? Physiology}

The basic steps when treating hypernatremia:

1. Treatment goals:

a. To gradually bring back plasma tonicity back to normal $^{[15]}$

b. Correct imbalances in sodium concentration

c. Correct underlying disorders

2. Be aware of:

a. The patient's volume status

b. Is the problem acute or chronic: Hypernatremia should be treated as if chronic unless there is proof that it has developed acutely

c. Frequently recheck serum sodium levels to monitor the treatment

3. Type of fluid

a. D5W: It is a hypotonic fluid relative to the serum where 11 of D5W would equal 11 of free water

b. $0.45 \mathrm{NS}$ : It is a hypotonic fluid relative to the serum where 11 of $0.45 \mathrm{NS}$ would equal $500 \mathrm{ml}$ of free water

c. 0.9NS: This is an isotonic fluid and is the fluid of choice for the initial management of shock where tissue perfusion is of utmost importance

4. Expected change in serum sodium over the next $24 \mathrm{~h}$ with the infusion of 11 of predecided IV fluid ${ }^{[15]}$ 
a. Change in serum sodium $=([$ infusate sodium - serum sodium $] /[$ total body water +1$])=$ "xyz"

- $\quad$ Total body water $=0.6 \times$ premorbid weight for young men; $0.5 \times$ premorbid weight for young women and elderly men; $0.45 \times$ premorbid weight for elderly women

5. Total amount of the fluid to be given, or the total duration

a. Replace water at a rate sufficient to correct hypernatremia, but slowly enough to avoid fatal complication of cerebral edema: Serum sodium concentration should be corrected at the rate of $0.5-1 \mathrm{mEq} / \mathrm{L} / \mathrm{h}$; not $>8-10 \mathrm{mEq} / \mathrm{L} /$ day

b. In addition to replacing the water deficit, anticipate and replace other ongoing fluid losses (GI, skin, respiratory) i. (10/"xyz" [as obtained from formula 4a] + ongoing fluid losses) over the next $24 \mathrm{~h}$

c. Correction using equations is not meant to be hard and fast but rather used as a guide with frequent monitoring of serum sodium levels as well as the clinical response.

\section{At the bedside}

This patient was hypotensive and clinically volume deplete on initial presentation. She was infused 0.9NS. Later, once her hemodynamics stabilized, IV fluids were changed to $0.45 \mathrm{NS}$ on April 2. Sodium levels were monitored frequently till they reached $145 \mathrm{mEq} / \mathrm{L}$.

\section{Conclusion}

Equilibration of urea across the cell membranes, ECF [urea] = ICF [urea] takes several hours. In conditions of high blood urea concentration, all of it is not reabsorbed at the level of MCD. Urea then behaves as an "effective" osmole leading to urea-induced solute diuresis with resultant EFWC.

\section{Declaration of patient consent}

The authors certify that they have obtained all appropriate patient consent forms. In the form the patient(s) has/have given his/her/their consent for his/her/their images and other clinical information to be reported in the journal. The patients understand that their names and initials will not be published and due efforts will be made to conceal their identity, but anonymity cannot be guaranteed.

\section{Financial support and sponsorship}

Nil.

\section{Conflicts of interest}

There are no conflicts of interest.

\section{RefEREnCES}

1. Espinel CH, Gregory AW. Differential diagnosis of acute renal failure. Clin Nephrol 1980;13:73-7.

2. Skorecki K, Chertow GM, Marsden PA, Taal MW, Yu AS, Wasser WG, editors. Disorders of sodium balance. In: Brenner and Rector's the Kidney. 10 ${ }^{\text {th }}$ ed. Philadelphia: Elsevier; 2016. p. 390-459.e16.

3. Skorecki K, Chertow GM, Marsden PA, Taal MW, Yu AS, Wasser WG, editors. Antihypertensive therapy. In: Brenner and Rector's the Kidney. $10^{\text {th }}$ ed. Philadelphia: Elsevier; 2016. p. 1640-701.e17.

4. Bhasin B, Velez JC. Evaluation of polyuria: The roles of solute loading and water diuresis. Am J Kidney Dis 2016;67:507-11.

5. Nguyen MK, Kurtz I. Derivation of a new formula for calculating urinary electrolyte-free water clearance based on the Edelman equation. Am J Physiol Renal Physiol 2005;288:F1-7.

6. Popli S, Tzamaloukas AH, Ing TS. Osmotic diuresis-induced hypernatremia: Better explained by solute-free water clearance or electrolyte-free water clearance? Int Urol Nephrol 2014;46:207-10.

7. Bodonyi-Kovacs G, Lecker SH. Electrolyte-free water clearance: A key to the diagnosis of hypernatremia in resolving acute renal failure. Clin Exp Nephrol 2008;12:74-8.

8. Skorecki K, Chertow GM, Marsden PA, Taal MW, Yu AS, Wasser WG, editors. Interpretation of electrolyte and acid-base parameters in blood and urine. In: Brenner and Rector's the Kidney. $10^{\text {th }}$ ed. Philadelphia: Elsevier; 2016. p. 804-45.e2.

9. Gowrishankar M, Lenga I, Cheung RY, Cheema-Dhadli S, Halperin ML. Minimum urine flow rate during water deprivation: Importance of the permeability of urea in the inner medulla. Kidney Int 1998;53:159-66.

10. Gault MH, Dixon ME, Doyle M, Cohen WM. Hypernatremia, azotemia, and dehydration due to high-protein tube feeding. Ann Intern Med 1968;68:778-91.

11. Gennari FJ, Kassirer JP. Osmotic diuresis. N Engl J Med 1974;291:714-20.

12. Skorecki K, Chertow GM, Marsden PA, Taal MW, Yu AS, Wasser WG, editors. Disorders of water balance. In: Brenner and Rector's the Kidney. $10^{\text {th }}$ ed. Philadelphia: Elsevier; 2016. p. 460-510.e11.

13. Shoker AS. Application of the clearance concept to hyponatremic and hypernatremic disorders: A phenomenological analysis. Clin Chem 1994;40:1220-7.

14. Skorecki K, Chertow GM, Marsden PA, Taal MW, Yu AS, Wasser WG, editors. Hemodialysis. In: Brenner and Rector's the Kidney. $10^{\text {th }}$ ed. Philadelphia: Elsevier; 2016. p. 2058-110.e17.

15. Overgaard-Steensen C, Ring T. Clinical review: Practical approach to hyponatraemia and hypernatraemia in critically ill patients. Crit Care 2013;17:206. 